Rapid Communication

\title{
Somatic mutations of the catalytic subunit of cyclic AMP- dependent protein kinase (PRKACA) gene in Japanese patients with several adrenal adenomas secreting cortisol
}

\author{
Yasuyo Nakajima ${ }^{1)^{*}}$, Takashi Okamura ${ }^{1)^{*}}$, Tamae Gohko ${ }^{1)}$, Tetsurou Satoh ${ }^{1)}$, Koshi Hashimoto ${ }^{1)}$, \\ Nobuyuki Shibusawa $^{1)}$, Atsushi Ozawa ${ }^{1)}$, Sumiyasu Ishii ${ }^{1)}$, Takuya Tomaru ${ }^{1)}$, Kazuhiko Horiguchi ${ }^{1)}$, \\ Shuichi Okada ${ }^{1)}$, Daisuke Takata ${ }^{2)}$, Nana Rokutanda ${ }^{2}$, Jun Horiguchi ${ }^{2)}$, Yoshito Tsushima ${ }^{3)}$, \\ Tetsunari Oyama ${ }^{4}$, Izumi Takeyoshi ${ }^{2)}$ and Masanobu Yamada ${ }^{1)}$ \\ 1) Department of Medicine and Molecular Science, Gunma University Graduate School of Medicine, Maebashi 371-8511, Japan \\ 2) Department of Thoracic and Visceral Organ Surgery, Gunma University Graduate School of Medicine, Maebashi 371-8511, Japan \\ 3) Department of Diagnostic Radiology and Nuclear Medicine, Gunma University Graduate School of Medicine, Maebashi 371 - \\ 8511, Japan \\ 4) Department of Diagnostic Pathology, Gunma University Graduate School of Medicine, Maebashi 371-8511, Japan
}

\begin{abstract}
Somatic mutations of the catalytic subunit of the cyclic AMP-dependent protein kinase (PRKACA) gene have recently been identified in about 35\% of cortisol-producing adenomas (CPAs), with the affected patients showing overt Cushing's syndrome. Since we recently reported higher prevalence of mutations of the KCNJ5 gene and associations with autonomous cortisol secretion in Japanese aldosterone-producing adenomas than in Western countries, there might be different features of CPAs between Japan and the West. We therefore investigated mutations of the PRKACA gene in Japanese patients with several adrenal tumors secreting cortisol, including overt Cushing's syndrome, subclinical Cushing's syndrome, and aldosterone-producing adenomas (APAs) co-secreting cortisol operated on at Gunma University Hospital. Of the 13 patients with CPA who showed overt Cushing's syndrome, 3 (23\%) had recurrent somatic mutations of the PRKACA gene, p.L206R (c.617 T>G), and there were no mutations in subclinical Cushing's syndrome. Among 33 APAs, 24 had somatic mutations of the KCNJ5 gene, either G151R or L168R, 11 (33\%) had autonomous cortisol secretion, but there were no mutations of the PRKACA gene. We established a PCR-restriction fragment length polymorphism assay and revealed that the mutated allele was expressed at a similar level to the wild-type allele. These findings demonstrated that 1) the prevalence of Japanese patients with CPA who showed overt Cushing's syndrome and whose somatic mutations in the PRKACA gene was similar to that in Western countries, 2) the mutation might be specific for CPAs causing overt Cushing's syndrome, and 3) the mutant PRKACA allele was expressed appropriately in CPAs.
\end{abstract}

Key words: PRKACA, Cortisol-producing adenomas, Japanese

OVERPRODUCTION of adrenal cortisol induces several characteristic manifestations, including moon face, buffalo hump, striae, thin skin, and central obesity, known as Cushing's syndrome $[1,2]$. Tumors secreting cortisol in patients who did not show any symptoms typical of Cushing's syndrome were described as

Submitted Jun. 13, 2014; Accepted Jun. 19, 2014 as EJ14-0282 Released online in J-STAGE as advance publication Jul. 25, 2014

Correspondence to: Masanobu Yamada, M.D., Ph.D., Department of Medicine and Molecular Science, Gunma University Graduate School of Medicine, 3-39-15 Showa-machi, Maebashi, Gunma 371-8511, Japan. E-mail: myamada@gunma-u.ac.jp

*These two authors contributed equally to this work. subclinical Cushing's syndrome [1, 3, 4], but this concept is not universal, and the definition differs among investigators and countries [5, 6]. In addition, we and others, particularly Japanese investigators, have reported an association of primary aldosteronism with mild autonomous cortisol secretion [7-9].

The mechanisms underlying the tumorigenesis of adrenal cortisol-producing adenomas (CPAs) and autonomous cortisol production are still largely unknown. However, Beuschlein et al. recently successfully identified the recurrent somatic mutation p.L206R (c.617T $>\mathrm{G}$ ) by exome analysis in the gene encoding PRKACA, which encodes the catalytic sub- 
unit of cyclic AMP-dependent protein kinase (protein kinase A [PKA]), in 22 of 59 (37\%) patients with CPA who showed overt Cushing's syndrome [10].

Goh et al. also identified the PRKACA mutation encoding p.L206R at a similar prevalence, namely, 35\% of PCAs associated with overt Cushing's syndrome [11]. Leu206 directly interacts with the regulatory subunit of PKA, PRKAR1A. The hotspot p.L206R mutation causes loss of this PRKAR1A binding, increasing the phosphorylation of downstream targets and causing constitutive activation of the PKA catalytic subunit, which induces overproduction of cortisol and cell proliferation [11].

We have recently reported high prevalence of somatic mutation in a potassium channel gene, KCNJ5, of approximately $70 \%$, in Japanese patients with adrenal aldosterone-producing adenomas (APAs) and some APAs co-secreting cortisol $[12,13]$. In contrast, in Western countries, the prevalence of the mutations has been reported to be approximately $35-40 \%$ of APAs, and cases of APAs co-secreting cortisol have rarely been reported [14].

Therefore, there may be differences of PRKACA mutations in CPAs and adrenal cortisol-secreting adenomas between Japan and Western countries. In the present study, we investigated the PRKACA mutations in several adrenal tumors secreting cortisol, including overt Cushing's syndrome, subclinical Cushing's syndrome, and APAs co-secreting cortisol.

\section{Subjects and Methods}

\section{Subjects}

We reviewed the medical records of 21 patients with CPA and 33 patients with APA, who were operated on at Gunma University Hospital during the period 20072013. Each subject provided written informed consent, and the study was approved by the ethics committee on human research of Gunma University. The diagnosis of Cushing's syndrome was made in 13 female cases (aged $54 \pm 13$ yr (mean \pm SD)) according to guidelines published by the Endocrine Society [1]. The diagnosis of primary aldosteronism (PA) was initially performed as previously reported $[7,15]$. We also examined morning and midnight cortisol levels, as well as $1 \mathrm{mg}$ dexamethasone suppression test (DST) results in all the patients with suspected PA $[7,8,16]$. Failure of cortisol to suppress the level to less than $3.0 \mu \mathrm{g} / \mathrm{dl}$ $(139.75 \mathrm{nmol} / \mathrm{L})$ in the DST was used as a parameter for autonomous cortisol secretion in this study.

Plasma aldosterone levels were measured with the RIA SPAC-S Aldosterone kit TFB; plasma renin activity, with the RIA Renin IRMA KIT "Daiichi" TFB; plasma cortisol, with the RIA Cortisol kit "TFB" TFB; and ACTH, with ECLIA Eclusys ACTH by Roche Diagnostics.

\section{RNA extraction and detection of mutations of PRKACA cDNA by PCR and direct sequencing}

All specimens of adrenal tumor were frozen in liquid nitrogen immediately after removal during operation. Total RNA was prepared from each adenoma using ISOGEN (Nippongene, Toyama, Japan) according to manufacturer's instructions. Then, cDNA was reverse-transcribed from $300 \mathrm{ng}$ of total RNA (TaqMan Reverse Transcription Reagents, Applied Biosystems, Tokyo, Japan). To sequence the PRKACA cDNA, $1.0 \mu \mathrm{L}$ of cDNA was used for the polymerase chain reaction (PCR), as previously reported [17]. PCR solutions were prepared according to the manual for AmpliTaq (Life Technologies, Carlsbad, CA, USA) with a final volume of $50 \mu \mathrm{L}$. Each primer used for PCR was set in a different exon, 5'F1, 5'-CCTGACCTTTGAGTATCTGCACT-3' (forward primer) and h3'R1, 5'-CGGCCATTTCATAGATAAGA ACC-3' (reverse primer) in putative exons 6 and 7 (ENST00000308677). After denaturing for $2 \mathrm{~min}$ at $94^{\circ} \mathrm{C}$, amplification was performed for 35 cycles at $94^{\circ} \mathrm{C}$ for $30 \mathrm{sec}, 58^{\circ} \mathrm{C}$ for $30 \mathrm{sec}$, and $72^{\circ} \mathrm{C}$ for 1 min using a GeneAmp PCR system 9700 (Applied Biosystems, Tokyo, Japan). The PCR products (244 bp) were purified with an AxyPrep PCR clean-up kit (AXYGEN Biosciences, Union City, CA, USA) for sequencing. These samples were directly sequenced using an Applied Biosystems 3730xl (Applied Biosystems, Tokyo, Japan).

In cases in which mutation of the PRKACA gene was identified, we sequenced the mutated nucleotide of the genomic DNA from peripheral blood using primers 5'-GTTTCTGACG GCTGGACTG-3' and 5'-CGGCCATTTCATAGATAAGAACC-3' under the same PCR conditions as described above.

\section{PCR-RFLP assay}

We performed a polymerase chain reaction-restriction fragment length polymorphism assay (PCRRFLP) in CPAs with p.L206R (c.617T >G), since this mutation produces a site that cannot be digested with the BciT130 I (EcoR II, Mva I) (Takara Shiga, Japan) 
restriction enzyme. The 213-bp fragment encompassing the $617 \mathrm{~T}>\mathrm{G}$ mutation in cDNA was generated using the primers 5'-CCTGACCTTTGAGTATCTGCACT-3' and 5'-CACCAGTCCACGGCCTTGTTGTA-3'. PCRs were performed as above. The wild-type cDNA was cut with BciT130 I into two fragments of $162 \mathrm{bp}$ and $52 \mathrm{bp}$ (not detected), while the mutated allele remained uncut, and similarly the wild-type genomic DNA was cut into fragments $127 \mathrm{bp}$ and $147 \mathrm{bp}$ in length. The fragments were resolved on a $2 \%$ agarose gel. We compared the density of the 213-bp and 162-bp fragments after digestion to evaluate the ratio of levels of the mutated and wild-type PRKACA mRNA. The bands were quantitatively measured using Molecular Imager FX (Bio-Rad Laboratories, Inc., Tokyo, Japan). All experiments were repeated at least twice.

\section{Statistical analysis}

All results are expressed as the mean $\pm \mathrm{SD}$ for continuous variables and as absolute numbers. Statistical analyses were performed with ANOVA and Student's $t$ test using JMP 10.0.2 (SAS Institute Inc., Cary, NC).

\section{Results}

\section{Mutations of the PRKACAgene in patients with CPAs and other adrenal adenomas secreting cortisol}

Table 1 shows the clinical features of patients with Cushing's syndrome. All patients showed symptoms typical of Cushing's syndrome. Mean tumor size (maximum diameter) on $\mathrm{CT}$ was $28 \pm 4 \mathrm{~mm}$. The 24-h urinary free cortisol excretion in 12 patients was over $200 \mu \mathrm{g} / \mathrm{day}$, except for 1 case with $81.8 \mu \mathrm{g} /$ day. In all patients, plasma ACTH levels were undetectable (Table 1). Furthermore, the pathology in all cases was confirmed as adrenocortical adenoma. We examined mutation of the PRKACA gene in these 13 patients and found that 3 CPAs had somatic mutations of the PRKACA gene. As shown in Fig. 1 (lower panel), mutations were concentrated at nucleotide $\mathrm{T} 617 \mathrm{bp}$ downstream of the translation start site, and the conversion of $\mathrm{T}$ to $\mathrm{G}$ causing the substitution of leucine (L) by arginine (R) at residue 206 (p.L206R), which is the same substitution as reported by Beuschlein et al. [10]. Furthermore, we also confirmed that there were no germline mutations of PRKACA in DNA from

Table 1 Clinical features of 13 patients with Cushing`s syndrome

\begin{tabular}{|c|c|c|c|c|c|c|c|c|c|c|c|c|c|}
\hline \multirow{2}{*}{\multicolumn{2}{|c|}{ Pt $\begin{array}{l}\text { Age } \\
(\mathrm{yr})\end{array}$}} & \multirow{2}{*}{ Sex } & \multirow{2}{*}{$\begin{array}{c}\text { Specific } \\
\text { cushingoid } \\
\text { signs } \\
\text { (Yes/No) }\end{array}$} & \multicolumn{3}{|c|}{$\begin{array}{l}\text { Metabolic disorders } \\
\text { (Yes/No) }\end{array}$} & \multirow{2}{*}{ complications } & \multirow{2}{*}{$\begin{array}{c}\mathrm{ACTH} \\
(\mathrm{pg} / \mathrm{mL})\end{array}$} & \multirow{2}{*}{$\begin{array}{l}\text { Midnight } \\
\text { serum } \\
\text { cortisol } \\
(\mu \mathrm{g} / \mathrm{dL})\end{array}$} & \multirow{2}{*}{$\begin{array}{c}24 \mathrm{~h} \text { urine } \\
\text { cortisol } \\
\text { ( } \mu \mathrm{g} / \text { day })\end{array}$} & \multirow{2}{*}{$1 \underset{(\mu \mathrm{g} / \mathrm{dL})}{\mathrm{mg} \text { DST }}$} & \multirow{2}{*}{$\begin{array}{c}\text { Tumor } \\
\text { Size } \\
(\mathrm{mm})\end{array}$} & \multirow{2}{*}{ PRKACA mutation } \\
\hline & & & & obesity & HT HL & $\mathrm{DM} / \mathrm{IGT}$ & & & & & & & \\
\hline 1 & 37 & $\mathrm{~F}$ & Yes & Yes & Yes Yes & Yes & renal stone & 1.0 & 13.8 & 295 & 15.4 & 28 & c.617 T>G (p.L206R) \\
\hline 2 & 67 & $\mathrm{~F}$ & Yes & Yes & Yes Yes & Yes & & $<5$ & 25.4 & 249 & $33.0^{*}$ & 20 & c.617 T>G (p.L206R) \\
\hline 3 & 68 & $\mathrm{~F}$ & Yes & No & Yes Yes & Yes & $\begin{array}{l}\text { osteoporosis, primary } \\
\text { aldosteronism }\end{array}$ & 1.0 & 13.3 & 81.8 & 12.8 & 21 & c.617 T>G (p.L206R) \\
\hline 4 & 71 & $\mathrm{~F}$ & Yes & Yes & Yes Yes & Yes & & $<5$ & 22.4 & 405 & 39.9 & 30 & Wild type \\
\hline 5 & 63 & $\mathrm{~F}$ & Yes & Yes & Yes Yes & Yes & hyperparathyroidism & 1.0 & 17.0 & 446 & 27.2 & 26 & Wild type \\
\hline 6 & 59 & $\mathrm{~F}$ & Yes & Yes & Yes Yes & Yes & & 1.0 & 15.8 & 331 & $* *$ & 25 & Wild type \\
\hline 7 & 54 & $\mathrm{~F}$ & Yes & Yes & Yes Yes & Yes & stroke & $<5$ & 17.2 & 492 & 16.9 & 30 & Wild type \\
\hline 8 & 33 & $\mathrm{~F}$ & Yes & Yes & Yes Yes & Yes & & $<5$ & 20.0 & 477 & 19.9 & 32 & Wild type \\
\hline 9 & 41 & $\mathrm{~F}$ & Yes & Yes & Yes No & No & small intestine tumor & 1.0 & 13.7 & 205 & 15.7 & 36 & Wild type \\
\hline 10 & 44 & $\mathrm{~F}$ & Yes & No & Yes No & No & $\begin{array}{l}\text { fracture, stroke, } \\
\text { renal stone }\end{array}$ & 1.0 & 13.4 & 318 & 13.9 & 30 & Wild type \\
\hline 11 & 65 & $\mathrm{~F}$ & Yes & Yes & Yes Yes & Yes & fracture & 1.0 & 23.1 & 217 & $27.9^{*}$ & 26 & Wild type \\
\hline 12 & 52 & $\mathrm{~F}$ & Yes & Yes & Yes No & Yes & uterine fibroids & 1.0 & 15.6 & 267 & 16.8 & 27 & Wild type \\
\hline 13 & 42 & $\mathrm{~F}$ & Yes & Yes & Yes Yes & Yes & $\begin{array}{l}\text { osteoporosis, } \\
\text { gastric ulcer }\end{array}$ & 1.0 & 21.7 & 272 & 24.2 & 30 & Wild type \\
\hline
\end{tabular}

PRKACA mutation represents a heterozygous mutation of c.617 T $>\mathrm{G}$ (p.L206R). M, male; $\mathrm{F}$, female. Specific cushingoid signs refer to the guidelines of the Endocrine Society. HT, hypertension, The diagnosis of hypertension was made according to the 2014 guidelines of The Japanese Society of Hypertension. DM/IGT includes diabetes mellitus and impaired glucose tolerance, The diagnosis of diabetes mellitus and glucose tolerance were made according to the 2006-2007 guidelines of The Japan Diabetes Society. HL, hyperlipidemia, Hyperlipidemia was evaluated according to the 2007 guidelines of Japan Atherosclerosis Society. $1 \mathrm{mg}$ DST, serum cortisol levels in the $1 \mathrm{mg}$ dexamethasone suppression test. Tumor size is the maximum diameter of the tumor observed in the CT study. *Pt. 2 and Pt. 11 underwent $8 \mathrm{mg}$ dexamethasone suppression test. ${ }^{* *}$ No data were available. ${ }^{* * *}$ Pt. 3 was diagnosed with primary aldosteronism at the opposite side of cortisol-producing adenoma by performing adrenal vein sampling. 
PRKACA Wild-type
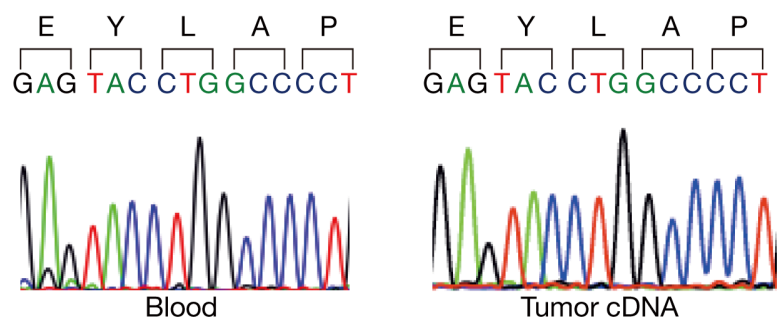

PRKACA c.617 T>G
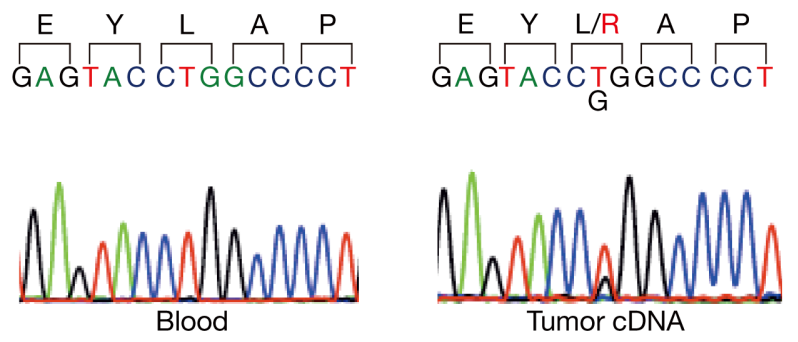

Fig. 1 Sequences of mutations of the PRKACA gene in CPAs Representative sequences of peripheral blood DNA (Blood) and tumor cDNA of the mutant PRKACA are depicted. L206R T/G represents heterozygosity for an T-to-G transition 617 bp from the translation start site in the PRKACA gene, resulting in a leucine-to-arginine substitution at codon 206 (c.617T $>$ G, p.L206R). No mutations were identified in the peripheral blood DNA. peripheral blood of the 3 patients with mutations (lower panel, Blood).

As shown in Table 2, we next examined the tumors of 8 patients who showed autonomous cortisol secretion. Serum ACTH levels in most patients were below $10 \mathrm{pg} / \mathrm{mL}$, except for patient 2 with $14.9 \mathrm{pg} / \mathrm{mL}$. Fractionated urine cortisol levels were within normal limits or slightly elevated, but below $150 \mu \mathrm{g} /$ day. None of the patients showed suppression of serum cortisol level below $3 \mu \mathrm{g} / \mathrm{dL}$ after overnight loading of $1 \mathrm{mg}$ of dexamethasone (1 mg DST). Mean tumor size was 32 $\pm 10 \mathrm{~mm}$. We found no mutations of the PRKACA gene in these 8 adenomas.

Table 3 shows the clinical features of 33 cases of APAs. Among these APAs, 24 were harboring somatic KCNJ5 mutations of either G151R or L168R, and 11 had autonomous cortisol secretion. None of the patients had any Cushingoid signs, except patient 11 in Table 3, who showed a slight moon face. However, these 11 cases showed no suppression of serum cortisol level below $3 \mu \mathrm{g} / \mathrm{dL}$ by $1 \mathrm{mg}$ DST. As seen in tumors showing subclinical Cushing's syndrome, urine cortisol levels of these 11 patients were within the normal range or slightly high, but below $150 \mu \mathrm{g} /$ day. We examined the mutation of the PRKACA gene in all of the 33 APAs, but there were no such mutations in tumors showing

Table 2 Clinical features of 8 patients with subclinical Cushing`s syndrome

\begin{tabular}{|c|c|c|c|c|c|c|c|c|c|c|c|c|c|c|}
\hline \multirow{2}{*}{$\mathrm{Pt}$} & \multirow{2}{*}{$\begin{array}{l}\text { Age } \\
\text { (yr) }\end{array}$} & \multirow{2}{*}{ Sex } & \multirow{2}{*}{$\begin{array}{c}\text { Specific } \\
\text { cushingoid } \\
\text { signs } \\
\text { (Yes/No) }\end{array}$} & \multicolumn{4}{|c|}{$\begin{array}{l}\text { Metabolic disorders } \\
\text { (Yes/No) }\end{array}$} & \multirow{2}{*}{ complications } & \multirow{2}{*}{$\begin{array}{c}\mathrm{ACTH} \\
(\mathrm{pg} / \mathrm{mL})\end{array}$} & \multirow{2}{*}{$\begin{array}{l}\text { Midnight } \\
\text { serum } \\
\text { cortisol } \\
(\mu \mathrm{g} / \mathrm{dL})\end{array}$} & \multirow{2}{*}{$\begin{array}{l}24 \mathrm{~h} \text { urine } \\
\text { cortisol } \\
\text { ( } \mu \mathrm{g} / \text { day) }\end{array}$} & \multirow{2}{*}{$\begin{array}{c}1 \mathrm{mg} \\
\mathrm{DST} \\
(\mu \mathrm{g} / \mathrm{dL})\end{array}$} & \multirow{2}{*}{$\begin{array}{l}\text { Tumor } \\
\text { Size } \\
(\mathrm{mm})\end{array}$} & \multirow{2}{*}{$\begin{array}{c}\text { PRKACA } \\
\text { mutation }\end{array}$} \\
\hline & & & & obesity & HT & HL & $\mathrm{DM} / \mathrm{IGT}$ & & & & & & & \\
\hline 1 & 57 & $\mathrm{~F}$ & No & Yes & Yes & Yes & Yes & & 8.8 & 5.0 & 25.2 & 3.4 & 35 & Wild type \\
\hline 2 & 54 & $\mathrm{~F}$ & No & Yes & Yes & Yes & Yes & breast cancer & 14.9 & 3.9 & 16.1 & 4.0 & 15 & Wild type \\
\hline 3 & 69 & $\mathrm{~F}$ & No & Yes & Yes & Yes & Yes & $\begin{array}{l}\text { primary } \\
\text { aldosteronism } \\
\text { Grave's disease }\end{array}$ & 1.0 & 9.4 & 51 & $12.4^{*}$ & 30 & Wild type \\
\hline 4 & 48 & $\mathrm{~F}$ & No & No & No & No & No & & 6 & $* *$ & 133 & 16.3 & 35 & Wild type \\
\hline 5 & 76 & $\mathrm{~F}$ & No & No & Yes & No & No & stroke & $<5$ & $* *$ & 43.6 & 6.8 & 30 & Wild type \\
\hline 6 & 66 & M & No & No & Yes & No & No & & 7.9 & 8.0 & 94.6 & 5.5 & 22 & Wild type \\
\hline 7 & 73 & F & No & No & Yes & No & No & & 6.7 & 4.0 & 29.1 & 3.8 & 40 & Wild type \\
\hline 8 & 60 & $\mathrm{~F}$ & No & Yes & Yes & Yes & Yes & $\begin{array}{l}\text { arteriosclerosis } \\
\text { obliterans }\end{array}$ & 5.0 & 9.6 & 71.4 & 12.9 & 48 & Wild type \\
\hline
\end{tabular}

PRKACA mutation represents a heterozygous mutation of c.617T $>\mathrm{G}$ (p.L206R). M, male; F, female. Specific cushingoid signs refer to the guidelines of the Endocrine Society. HT, hypertension. DM/IGT includes diabetes mellitus and impaired glucose tolerance. HL, hyperlipidemia. $1 \mathrm{mg}$ DST, serum cortisol levels in the $1 \mathrm{mg}$ dexamethasone suppression test. Tumor size is the maximum diameter of the tumor observed in the CT study. ${ }^{*}$ Pt. 3 underwent $8 \mathrm{mg}$ dexamethasone suppression test. ${ }^{* * *}$ No data were available. ${ }^{* * *}$ Pt. 3 was diagnosed with primary aldosteronism at the opposite side of cortisol-producing adenoma by performing adrenal vein sampling. 
Table 3 Clinical features of 33 patients with aldosterone-producing adenoma with or without hypercortisolism

\begin{tabular}{|c|c|c|c|c|c|c|c|c|c|c|c|c|}
\hline $\mathrm{Pt}$ & $\begin{array}{l}\text { Age } \\
\text { (yr) }\end{array}$ & Sex & $\begin{array}{c}\text { Specific } \\
\text { cushingoid } \\
\text { signs } \\
\text { (Yes/No) }\end{array}$ & $\begin{array}{c}\text { Mild } \\
\text { hypercortisolism } \\
\text { (Yes/No) }\end{array}$ & $\underset{(\mathrm{pg} / \mathrm{mL})}{\mathrm{PAC}}$ & $\begin{array}{c}\text { PRA } \\
\text { (ng/mL/h) }\end{array}$ & $1 \mathrm{mg}$ DST & $\begin{array}{c}\mathrm{ACTH} \\
(\mathrm{pg} / \mathrm{mL})\end{array}$ & $\begin{array}{l}\text { Midnight } \\
\text { serum } \\
\text { cortisol } \\
(\mu \mathrm{g} / \mathrm{dL})\end{array}$ & $\begin{array}{l}24 \mathrm{~h} \text { urine } \\
\text { cortisol } \\
\text { ( } \mu \mathrm{g} / \text { day) }\end{array}$ & $\begin{array}{l}\text { PRKACA } \\
\text { mutation } \\
\text { (Yes/No) }\end{array}$ & $\begin{array}{l}\text { KCNJ5 } \\
\text { Mutation }\end{array}$ \\
\hline 1 & 30 & $\mathrm{~F}$ & No & Yes & 580 & 0.3 & Yes & 16.4 & 6 & 37.1 & No & c. $451 \mathrm{G}>\mathrm{A}(\mathrm{p} . \mathrm{G} 151 \mathrm{R})$ \\
\hline 2 & 53 & $\mathrm{~F}$ & No & Yes & 393 & 0.1 & Yes & 34 & 11.4 & 118 & No & c.503T $>$ G (p.L168R) \\
\hline 3 & 48 & $\mathrm{~F}$ & No & Yes & 888 & 0.4 & Yes & 16.7 & 3.4 & 44 & No & c.503T $>\mathrm{G}$ (p.L168R) \\
\hline 4 & 60 & $\mathrm{~F}$ & No & Yes & 114 & 0.4 & Yes & $<5$ & 10.5 & 86.5 & No & Wild type \\
\hline 5 & 48 & $\mathrm{~F}$ & No & Yes & 231 & 0.4 & Yes & 6.8 & 5 & 35.9 & No & Wild type \\
\hline 6 & 57 & M & No & Yes & 526 & 0.1 & Yes & 31.6 & 5.1 & 32.8 & No & c. $451 \mathrm{G}>\mathrm{A}$ (p.G151R) \\
\hline 7 & 58 & M & No & Yes & 742 & $<0.1$ & Yes & 14 & 5.4 & 59.1 & No & c. $451 \mathrm{G}>\mathrm{C}(\mathrm{p} . \mathrm{G} 151 \mathrm{R})$ \\
\hline 8 & 75 & M & No & Yes & 132 & 0.2 & Yes & 13.8 & 5 & 73.3 & No & Wild type \\
\hline 9 & 74 & M & No & Yes & 343 & 0.1 & No & 82.5 & 14.2 & 129 & No & Wild type \\
\hline 10 & 53 & M & No & Yes & 330 & 0.5 & Yes & 22.5 & 9.4 & 63.3 & No & Wild type \\
\hline 11 & 51 & $\mathrm{~F}$ & Yes & Yes & 1330 & 0.6 & Yes & $<5$ & 12.3 & $*$ & No & c. $451 \mathrm{G}>\mathrm{A}(\mathrm{p} . \mathrm{G} 151 \mathrm{R})$ \\
\hline 12 & 68 & $\mathrm{~F}$ & No & No & 139 & $<0.1$ & $*$ & 22.3 & 3.6 & 21.3 & No & Wild type \\
\hline 13 & 26 & $\mathrm{~F}$ & No & No & 500 & $<0.1$ & No & 17.1 & 1.7 & * & No & c.503T $>$ G (p.L168R) \\
\hline 14 & 35 & $\mathrm{~F}$ & No & No & 287 & 0.3 & No & 19.7 & 4.7 & 33.3 & No & c. $451 \mathrm{G}>\mathrm{C}$ (p.G151R) \\
\hline 15 & 61 & $\mathrm{~F}$ & No & No & 366 & $<0.1$ & No & 14.9 & 2.9 & 58.2 & No & Wild type \\
\hline 16 & 64 & M & No & No & 521 & $<0.1$ & No & 27.9 & 3.7 & $*$ & No & c. $451 \mathrm{G}>\mathrm{A}(\mathrm{p} . \mathrm{G} 151 \mathrm{R})$ \\
\hline 17 & 31 & M & No & No & 353 & $<0.1$ & No & 29.3 & 2.2 & 39.2 & No & c. $451 \mathrm{G}>\mathrm{A}$ (p.G151R) \\
\hline 18 & 61 & M & No & No & 484 & 0.2 & No & 22 & 1.4 & 102 & No & Wild type \\
\hline 19 & 41 & $\mathrm{~F}$ & No & No & 176 & 0.2 & No & 34.3 & 1.0 & $*$ & No & c. $451 \mathrm{G}>\mathrm{A}(\mathrm{p} . \mathrm{G} 151 \mathrm{R})$ \\
\hline 20 & 63 & $\mathrm{~F}$ & No & No & 363 & $<0.1$ & No & 29.5 & 2.3 & 30.5 & No & c. $451 \mathrm{G}>\mathrm{C}(\mathrm{p} . \mathrm{G} 151 \mathrm{R})$ \\
\hline 21 & 73 & $\mathrm{~F}$ & No & No & 260 & $<0.1$ & $*$ & 12.5 & $*$ & 23.4 & No & Wild type \\
\hline 22 & 50 & M & No & No & 426 & 0.2 & No & 10.8 & 2.5 & 36.2 & No & c. $451 \mathrm{G}>\mathrm{A}(\mathrm{p} . \mathrm{G} 151 \mathrm{R})$ \\
\hline 23 & 55 & M & No & No & 299 & 0.1 & No & 28.4 & 1.8 & 52 & No & c. $451 \mathrm{G}>\mathrm{A}$ (p.G151R) \\
\hline 24 & 36 & $\mathrm{~F}$ & No & No & 542 & 0.2 & No & 11.5 & 5.9 & 49.6 & No & c.503T $>\mathrm{G}$ (p.L168R) \\
\hline 25 & 50 & M & No & No & 1330 & $<0.1$ & No & 17.4 & 29.5 & 29.5 & No & c. $451 \mathrm{G}>\mathrm{A}$ (p.G151R) \\
\hline 26 & 52 & M & No & No & 693 & 0.3 & No & 44 & 4.4 & 132 & No & c. $451 \mathrm{G}>\mathrm{A}$ (p.G151R) \\
\hline 27 & 42 & $\mathrm{~F}$ & No & No & 358 & 0.9 & * & 15 & 2.4 & $*$ & No & c. $503 \mathrm{~T}>\mathrm{G}(\mathrm{p} . \mathrm{L} 168 \mathrm{R})$ \\
\hline 28 & 65 & M & No & No & 1990 & $<0.1$ & No & 43.6 & 3.4 & 69.6 & No & c. $451 \mathrm{G}>\mathrm{C}$ (p.G151R) \\
\hline 29 & 50 & $\mathrm{~F}$ & No & No & 88.9 & 0.3 & No & 20.2 & 1.7 & 74.8 & No & c. $451 \mathrm{G}>\mathrm{A}(\mathrm{p} . \mathrm{G} 151 \mathrm{R})$ \\
\hline 30 & 41 & $\mathrm{~F}$ & No & No & 224 & 0.3 & No & 44.1 & 7.4 & 33.1 & No & c.503T $>\mathrm{G}(\mathrm{p} . \mathrm{L} 168 \mathrm{R})$ \\
\hline 31 & 32 & M & No & No & 1212 & 0.4 & No & 46 & 2.5 & 73.4 & No & c. $451 \mathrm{G}>\mathrm{A}(\mathrm{p} . \mathrm{G} 151 \mathrm{R})$ \\
\hline 32 & 50 & $\mathrm{~F}$ & No & No & 517 & 0.4 & $*$ & 23.8 & $*$ & $*$ & No & c. $451 \mathrm{G}>\mathrm{C}$ (p.G151R) \\
\hline 33 & 46 & M & No & No & 130 & 0.1 & No & 22.3 & 3.7 & 99.2 & No & c. $451 \mathrm{G}>\mathrm{C}$ (p.G151R) \\
\hline
\end{tabular}

PRKACA mutation represents a heterozygous mutation of c.617T $>\mathrm{G}$ (p.L206R). KCNJ5 mutation represents a heterozygous mutation of c.451G $>$ C (p.G151R), c.451G $>$ A (p.G151R), or c.503T $>$ G (p.L168R). M, male; F, female. Specific cushingoid signs refer to the guidelines of the Endocrine Society. $1 \mathrm{mg}$ DST, serum cortisol levels in the $1 \mathrm{mg}$ dexamethasone suppression test. Mild hypercortisolism was defined as at least one abnormal result of suppressed plasma ACTH levels below $10 \mathrm{pg} / \mathrm{mL}$, midnight serum cortisol levels above 7.5 $\mu \mathrm{g} / \mathrm{dL}$, or a $1 \mathrm{mg}$ dexamethasone suppression test result $>3.0 \mu \mathrm{g} / \mathrm{dL}$. $1 \mathrm{mg}$ DST, a $1 \mathrm{mg}$ dexamethasone suppression test result $>3.0 \mu \mathrm{g} /$ $\mathrm{dL}$ is indicated as Yes. ${ }^{*}$ No data were available. 
either pure APA or APA co-secreting cortisol.

\section{Ratio of wild-type and mutated PRKACA mRNA levels examined by PCR-RFLP}

To evaluate the expression of mutant mRNA, we performed a PCR-RFLP assay on the CPAs with the mutation p.L206R (c.617T > G), namely, patients 1-3 in Table 1. As shown in Fig. 2, the 213-bp band corresponded to the amplified cDNA and the 273-bp band was amplified genomic DNA that included a short intron, $148 \mathrm{bp}$ in length. The complete digestion by the enzyme was confirmed by PCR fragments of the genomic DNA, and no band remained after digestion. The density of the 213-bp fragment after digestion with the BciT130 I restriction enzyme was similar to that of the 162-bp fragment (the ratio of 213-bp /162-bp fragment $(101.8 \pm 1.4 \%, n=3))$, suggesting that the mutant mRNA c.617T $>$ G may be expressed at a level similar to that of the wild type.

\section{Discussion}

In the present study, we identified heterozygosity for an T-to-G transition $617 \mathrm{bp}$ from the translation start site in the PRKACA gene (c.617T $>\mathrm{G})$ in 3 of 13 of the patients, which is the same mutation as reported by Beuschlein et al., resulting in a leucine-to-arginine substitution at codon 206 (p.L206R) [10]. Beuschlein et al. reported another mutation, c.595_596insCAC, in 1 case of overt Cushing's syndrome [10] . However, we did not find the same mutation in our cases. During the preparation of this manuscript Cao et al. and Sato et al. reported a higher prevalence (approximately $67 \%$ and $52 \%$, respectively) of the same mutation of the PRKACA gene in Chinese and Japanese CPAs showing overt Cushing's syndrome $[18,19]$. However, we found a similar prevalence of the mutation as that in Western countries. This may be due to differences in the severity of disease or environmental factors, although this requires further study.

Although the term "preclinical" Cushing's syndrome was previously proposed, the term "subclinical" Cushing's syndrome describes this condition more accurately, as it does not imply any assumption about the further development of a clinically overt syndrome $[20,21]$. Since the prevalence of overt Cushing's syndrome caused by adrenal adenoma in the general population is markedly lower than the prevalence of subclinical Cushing's syndrome in patients with clinically

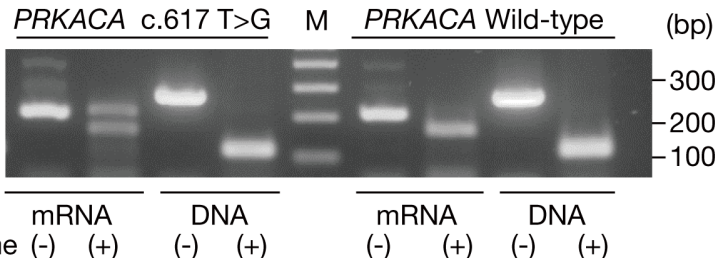

Enzyme $(-)(+) \quad(-) \quad(+) \quad(-) \quad(+) \quad(-) \quad(+)$

Fig. 2 PCR-RFLP assay of CPAs with c.617T $>$ G, p.L206R The wild-type fragment had the site digested by the BciT130 I restriction enzyme. The 213-bp PCR product encompassing the $617 \mathrm{~T}>\mathrm{G}$ mutation was digested with BciT130 I, and the fragments were resolved on a $2 \%$ agarose gel. The wild-type allele was cut into two fragments of 162- and 52-bp, while the mutated allele remained uncut. Similarly, the wild-type genomic DNA was cut into fragments $127 \mathrm{bp}$ and $147 \mathrm{bp}$ in length. We compared the density of the 213-bp and 162-bp fragments after digestion to evaluate the ratio of the levels of mutated and -wild-type PRKACA mRNA. We found that the mutant mRNA was expressed at a level similar to that in the wild-type. Representative data are shown. 'Enzyme' refers to digestion with a restriction enzyme, BciT130 I, and lane $\mathrm{M}$ is a molecular marker ladder.

non-functioning adrenal adenoma, it is rather inappropriate to consider subclinical Cushing's syndrome as an early stage of the development of overt hypercortisonemia $[20,22]$. Neither we nor Beuschlein et al. found mutations of the PRKACA gene in cases that showed subclinical Cushing's syndrome, so these findings further support the evidence that the origin of the tumors showing overt Cushing's syndrome differs from that of tumors showing subclinical Cushing's syndrome [10]. Although Sato et al. found the mutation in one case out of 9 tumors showing subclinical Cushing's syndrome, this may be due to the difference of the definition of subclinical Cushing's syndrome used for the diagnosis [19]. Sato et al. diagnosed patients who had an incidentally discovered adrenocortical adenoma and no typical symptoms or signs of Cushing's syndrome.

We previously reported that some APAs showing clear autonomous cortisol secretion had mutation of the KCNJ5 gene, suggesting that these tumors had the same features as APAs not co-secreting cortisol [13]. In a previous study, we defined the patients with all of the following criteria as having "clear cortisol secretion": 1) low ACTH level $<10 \mathrm{pg} / \mathrm{mL}, 2)$ suppressed accumulation of adosterol in scintigraphy on the intact side of the adrenal gland, and 3) post-adrenal insufficiency [13]. In the present study, we used serum morning cortisol level not being suppressed below $3 \mu \mathrm{g} / \mathrm{dL}$ 
by $1 \mathrm{mg}$ DST as a parameter of mild hypercortisolemia, but we did not find any PRKACA mutations in these tumors, even without KCNJ5 mutations. Furthermore, some APAs co-secreting cortisol had KCNJ5 mutation, suggesting that these tumors seem to be close to the features of APAs, rather than CPAs.

We established a simple assay to detect the mutation hotspot of the PRKACA gene using PCR-RFLP. The mutation causes loss of the enzyme site for digestion by the BciT130 I restriction enzyme. Although the sequence spike of the mutated allele seems to be lower than that of the wild-type allele in the present study and the same phenomenon has been described in reports by Beuschlein et al. [10] and Cao et al. [18], the results demonstrate that the mutated allele was expressed as was the wild-type allele.

Cao et al. also identified other somatic mutations co-localizing with PRKACA mutations in CPAs, including activating CTNNB1 mutations and an APC truncating mutation, activating GNAS (stimulatory G-protein $\alpha$ subunit), mutations in cancer-related genes such as ARIDIA and STAT3, and recurrently mutated GPR98 [18]. Sato et al. also found a GNAS mutation in some CPAs [19]. In addition, Goh et al. reported that some CPAs had many somatic copy number variants (CNVs), with frequent deletion of $C D C 42$ and CDKN2A, amplification of $5 \mathrm{q} 31.2$, mutations of TP53 or RB1, CTNNB1 (b-catenin), or GNAS [11]. In the present study, we did not find PRKACA mutations in any of the cases of subclinical Cushing's syndrome and APAs associated with cortisol. Therefore, the other mutations mentioned above may be involved in the pathophysiology of cortisol secretion in these tumors.

\section{Acknowledgements}

This study were supported in part by a Health and Labor Sciences Grant for Research on Measures for Intractable Disease (M.Y.) and KAKENHI (Grant-inAid for Reseach Activity Start-up 25893026) (Y.N.).

We thank all the medical and co-medical staff as well as graduate students involved in the patient care.

\section{Disclosure Summary}

All authors have nothing to disclose.

\section{References}

1. Nieman L, Biller B, Findling J, Newell-Price J, Savage M, et al. (2008) The diagnosis of Cushing's syndrome: an Endocrine Society Clinical Practice Guideline. J Clin Endocrinol Metab 93: 1526-1540.

2. Newell-Price J, Bertagna X, Grossman AB, Nieman LK (2006) Cushing's syndrome. Lancet 367: 1605-1617.

3. Rossi R, Tauchmanova L, Luciano A, Di Martino M, Battista C, et al. (2000) Subclinical Cushing's syndrome in patients with adrenal incidentaloma: clinical and biochemical features. J Clin Endocrinol Metab 85: 1440 1448 .

4. Terzolo M, Reimondo G, Bovio S, Angeli A (2004) Subclinical Cushing's syndrome. Pituitary 7: 217-223.

5. Grumbach M, Biller B, Braunstein G, Campbell K, Carney J, et al. (2003) Management of the clinically inapparent adrenal mass ("incidentaloma"). Ann Intern Med 138: 424-429.

6. Tsagarakis S, Vassiliadi D, Thalassinos N (2006) Endogenous subclinical hypercortisolism: Diagnostic uncertainties and clinical implications. $J$ Endocrinol Invest 29: 471-482.

7. Nakajima Y, Yamada M, Taguchi R, Satoh T, Hashimoto $\mathrm{K}$, et al. (2011) Cardiovascular complications of patients with aldosteronism associated with autonomous cortisol secretion. J Clin Endocrinol Metab 96: 2512-2518.
8. Adachi J, Hirai Y, Terui K, Nakano T, Fukuda Y, et al. (2003) A report of 7 cases of adrenal tumors secreting both cortisol and aldosterone. Intern Med 42: 714-718.

9. Späth M, Korovkin S, Antke C, Anlauf M, Willenberg HS (2011) Aldosterone- and cortisol-co-secreting adrenal tumors: the lost subtype of primary aldosteronism. Eur J Endocrinol 164: 447-455.

10. Beuschlein F, Fassnacht M, Assié G, Calebiro D, Stratakis CA, et al. (2014) Constitutive activation of PKA catalytic subunit in adrenal Cushing's syndrome. N Engl J Med 370: 1019-1028.

11. Goh G, Scholl UI, Healy JM, Choi M, Prasad ML, et al. (2014) Recurrent activating mutation in PRKACA in cortisol-producing adrenal tumors. Nat Genet 46: 613617.

12. Taguchi R, Yamada M, Nakajima Y, Satoh T, Hashimoto K, et al. (2012) Expression and Mutations of KCNJ5 mRNA in Japanese Patients with Aldosterone-Producing Adenomas. J Clin Endocrinol Metab 97: 1311-1319.

13. Yamada M, Nakajima Y, Taguchi R, Okamura T, Ishii S, et al. (2012) KCNJ5 mutations in aldosterone- and cortisol-co-secreting adrenal adenomas. Endocr J 59: 735741.

14. Mulatero P, Monticone S, Rainey WE, Veglio F, Williams TA (2013) Role of KCNJ5 in familial and spo- 
radic primary aldosteronism. Nat Rev Endocrinol 9: 104-112.

15. Funder J, Carey R, Fardella C, Gomez-Sanchez C, Mantero F, et al. (2008) Case Detection, Diagnosis, and Treatment of Patients with Primary Aldosteronism: An Endocrine Society Clinical Practice Guideline. J Clin Endocrinol Metab 93: 3266-3281.

16. Hiraishi K, Yoshimoto T, Tsuchiya K, Minami I, Doi M, et al. (2011) Clinicopathological features of primary aldosteronism associated with subclinical Cushing's syndrome. Endocr J 58: 543-551.

17. Ishida E, Yamada M, Horiguchi K, Taguchi R, Ozawa A, et al. (2011) Attenuated expression of menin and p27 (Kip1) in an aggressive case of multiple endocrine neoplasia type 1 (MEN1) associated with an atypical prolactinoma and a malignant pancreatic endocrine tumor. Endocr J 58: 287-296.

18. Cao Y, He M, Gao Z, Peng Y, Li Y, et al. (2014)
Activating Hotspot L205R Mutation in PRKACA and Adrenal Cushing's Syndrome. Science 344: 913-917.

19. Sato Y, Maekawa S, Ishii R, Sanada M, Morikawa T, et al. (2014) Recurrent somatic mutations underlie corticotropin-independent Cushing's syndrome. Science 344: 917-920.

20. Chiodini I (2011) Clinical review: Diagnosis and treatment of subclinical hypercortisolism. J Clin Endocrinol Metab 96: 1223-1236.

21. Barzon L, Sonino N, Fallo F, Palu G, Boscaro M (2003) Prevalence and natural history of adrenal incidentalomas. Eur J Endocrinol 149: 273-285.

22. Mantero F, Terzolo M, Arnaldi G, Osella G, Masini A, et al. (2000) A survey on adrenal incidentaloma in Italy. Study Group on Adrenal Tumors of the Italian Society of Endocrinology. J Clin Endocrinol Metab 85: 637644. 